\section{Characteristics of Fire Blight Cankers following Shoot Inoculations of Three Apple Cultivars}

\author{
A.R. Biggs \\ West Virginia University, University Experiment Farm, P. O. Box 609, \\ Kearneysville, WV 25430
}

Additional index words. Malus domestics, Erwinia amylovora

\begin{abstract}
Three apple (Malus domestics Borkh.) cultivars varying in susceptibility to Erwinia amylovora (Burr.) Winslow et al., the causal agent of tire blight, were inoculated at biweekly intervals during the growing season. Data were collected on percent infection, canker length, and canker margin quality (a reflection of the overwintering status of the infection). There was a significant cultivar $\times$ noculation date interaction, indicating that cultivars that are more susceptible to the pathogen are more likely to develop cankers with indeterminate margins. For 'Cortland' and 'Jonathan', but not 'Delicious', there was a significant linear trend toward forming indeterminate cankers as inoculations were made later in the season. Cankers initiated earlier in the season were more likely to be determinate, which suggests that later-season infections on susceptible cultivars carry over inoculum to the following season. No specific switch-over period from determinateto indeterminate-type cankers could be identified, and canker margin qualities changed gradually during the growing season. As expected, 'Delicious' appeared resistant to tire blight in this study, based on percent infection, canker length, and canker margin type, whereas 'Cortland' and 'Jonathan' appeared moderately and highly susceptible, respectively. 'Delicious' was more likely to form cankers with determinate margins, which suggests that cankers formed on this cultivar are less likely to produce inoculum in the spring than the other two cultivars.
\end{abstract}

Fire blight, caused by the bacterial pathogen Erwinia amylovora, is one of the most destructive diseases of apple and pear (Pyrus communis L.) trees throughout the world (van der Zwet and Keil, 1979). The disease can be devastating in apple and pear orchards, frequently killing fruiting spurs, shoots, branches, sprouts, and entire trees. It is an extremely difficult pathogen to eradicate, and once established in the orchard, it can be costly and labor-intensive to control. Current management strategies include the use of predictive models (Steiner and Lightner, 1991), timely applications of copper and streptomycin, and pruning to remove overwintering cankers. Control practices are directed toward reducing or eliminating primary inoculum sources (van der Zwet and Keil, 1979).

Most researchers who have studied fire blight agree that the pathogen causes two types of cankers, determinate and indeterminate (Schouten, 1992). Sackett(1911) was the first to discern differences between types of

Received for publication 20 Aug. 1993. Accepted for publication 11 Jan. 1994, This is Scientific Article no, 2428 from the West Virginia Univ. Agricultural and Forestry Experiment Station, Appreciation is extended to Lynne Hightower for technical assistance and to Paul Steiner for assisting in the evaluation of cankers. The cost of publishing this paper was defrayed in part by the payment of page charges. Under postal regulations, this paper therefore must be hereby marked advertisement solely to indicate this fact. fire" blight cankers on pear. In apple, Miller (1929) observed that cankers showing no line of demarcation between diseased and healthy tissues produced infectious bacteria the following spring, whereas cankers with definite demarcation lines at the canker margin usually were inactive. In general, both canker types indirectly result from the downward spread of bacteria following infection of blossoms, fruiting spurs, and shoots (Beer, 1979). Upon host entry, the bacterial cells multiply and spread intercellularly through the cortical parenchyma and may enter the xylem and phloem, where they then invade systemically into supporting limbs and the main trunk. As foliar expansion and shoot growth slow down later in the season, invasion slows and eventually ceases. In indeterminate cankers, the bacteria apparently survive in the living phloem tissue around the canker margin (Miller, 1929). In determinate cankers, a periderm forms around the invaded tissues, isolating them and preventing further spread of the pathogen in the host. The pathogen is sequestered from living host tissues due to the impervious nature of the lignified, suberized barrier [although the pathogen is still occasionally able to survive the winter in determinate cankers (Schouten, 1992)]. For this reason, determinate cankers have sometimes been referred to as "closed cankers," and characteristically, they possess wrinkled, roughened, cracked, or raised margins. In some cases (i.e., Crataegus), however, this periderm barrier may be absent or incompletely formed (Hockenhull, 1974), thus creating a terium may overwinter. Such indeterminatemore tolerable microclimate in which the bac- type cankers are thought to be the major contributors of primary inoculum in the spring, via ooze production and extension of cankers in healthy tissues (Beer, 1979; Beer and Norelli, 1977; Steiner and Lightner, 1991; van der Zwet, 1969). The only study on the etiology of canker type stated that indeterminate cankers tended to form later in the growing season and in higher frequency on susceptible cultivars (Beer and Norelli, 1977). However, their observations on controlled inoculations were limited to nursery-grown trees infected in either July or September. The objective of the present study was to examine the effects of inoculation date on three apple cultivars having different degrees of resistance and to observe whether a seasonal shift occurred in the formation of the two canker types.

\section{Materials and Methods}

The experiment was initiated in May 1992, at the West Virginia Univ. Experiment Farm, Kearneysville. The three cultivars selected for this experiment were 'Jonathan' (susceptible) on M.111 rootstock, 'Cortland' (moderately susceptible) on M.111 rootstock, and 'Redchief (Campbell) Delicious' (resistant) on M.7 a rootstock (van der Zwet and Keil, 1979). Inoculation dates were 19 May; 2, 17, and 30 June; 14 and 28 July; and 13 Aug. (no infections occurred from inoculations made at the latter date). Current-year's shoots were selected at each inoculation date and then were inoculated with a hypodermic needle on the shoot apex just below the third leaf on 19 May and 2 June and, because of low infection rates from the 2 June inoculations, just below the second leaf in all subsequent inoculations with $1 \times 10^{8}$ colony-forming units of WV strain \#58 1/ml (from T. van der Zwet, U.S. Dept. of Agriculture-Agncultural Research Service, Kearneysville, W. Va.). Four shoots on each of four trees per cultivar were inoculated on each of the seven dates (28 trees total per cultivar). Number of leaves on four noninoculated shoots per tree were determined at the time of inoculation to assess the growth stage of the trees. Canker length was monitored biweekly during the season through 30 Aug., and then in December. Canker margins were rated visually in Apr. 1993, on a scale of 1 to 4 , with $1=$ severe cracking with well-defined margins (determinate), $2=$ moderate cracking with moderately defined margins (mostly determinate), $3=$ little visible cracking with poorly defined margins (mostly indeterminate), and $4=$ no visible cracking and margins not defined (indeterminate) (Beer and Norelli, 1977). Data on mean canker length were tested with analysis of variance using a full factorial design. Data on canker margin rating were converted to frequency (arcsin-transformed percent) (Steel and Tome, 1980) and analyzed with a general linear models procedure for unequal sample numbers (PROC GLM, SAS Institute, 1987). Seasonal trends in canker margin characteristics and the presence of associations among the various observations were analyzed with linear regression and correlation analysis, respectively (SAS Institute, 1987). 


\section{Results and Discussion}

Analysis of the canker margin ratings resulting from inoculations made on seven dates revealed a significant cultivar $\times$ date interaction. 'Delicious' exhibited uniformly determinate canker ratings from inoculations made at different times during the season (Fig. 1B), whereas 'Cortland' and 'Jonathan' exhibited cankers with increasingly indeterminate margins as inoculations were made later in the growing season (Fig. $1 \mathrm{~A}$ and $\mathrm{C}$ ). This pattern was most noticeable in 'Jonathan', the cultivar regarded as most highly susceptible to $E$. amylovora (van der Zwet and Keil, 1979). Based on canker margin appearance, 'Jonathan' was the most susceptible cultivar (mean rating $=2.4)$, followed by 'Cortland' (mean rating $=1.6)$, mid 'Delicious' (mean rating $=1.1)($ Table 1). Cultivar differences in mean canker rating were significant $(P \leq 0.05)$.

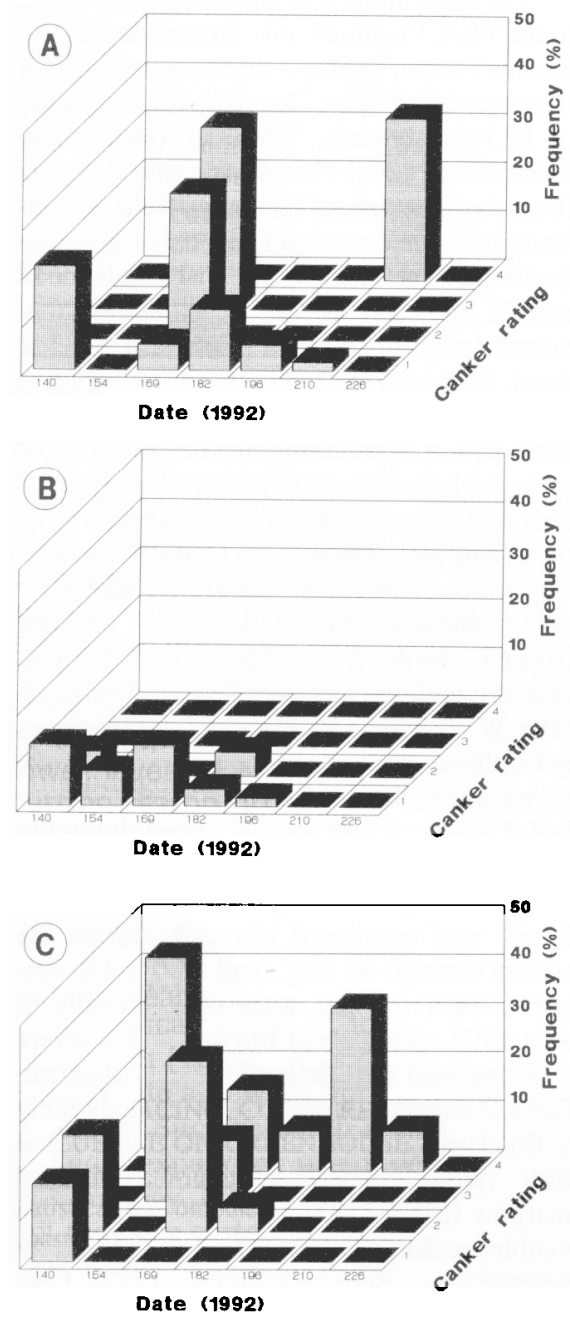

Fig. 1. Frequency (percent) of canker margin ratings from fire blight cankers initiated at various Julian dates during the 1992 growing season for three apple cultivars: (A) 'Cortland', (B) 'Delicious', and (C) 'Jonathan'. Canker margins rated on a scale of 1 to 4 , with $1=$ severe cracking with well-defined margins (determinate), 2 = moderate cracking with moderately defined margins (mostly determinate), $3=$ little visible cracking with poorly defined margins (mostly indeterminate), and $4=$ no visible cracking and margins not defined (indeterminate).

Table 1. Inoculation date, percent infection, mean canker length, and mean canker margin rating for 'Delicious', 'Cortland', and 'Jonathan' apple trees inoculated with the tire blight bacterium in 1992.

\begin{tabular}{|c|c|c|c|c|c|c|c|c|c|}
\hline \multirow[b]{2}{*}{$\begin{array}{l}\text { Inoculation } \\
\text { date }\end{array}$} & \multicolumn{3}{|c|}{ Delicious } & \multicolumn{3}{|c|}{ Cortland } & \multicolumn{3}{|c|}{ Jonathan } \\
\hline & $\begin{array}{c}\text { Infection } \\
(\%)\end{array}$ & $\begin{array}{l}\text { Canker } \\
\text { length } \\
(\mathrm{cm})\end{array}$ & $\begin{array}{c}\text { Canker }^{2} \\
\text { margin } \\
\text { rating }\end{array}$ & $\begin{array}{c}\text { Infection } \\
(\%)\end{array}$ & $\begin{array}{c}\text { Canker } \\
\text { length } \\
(\mathrm{cm})\end{array}$ & $\begin{array}{c}\text { Canker } \\
\text { margin } \\
\text { rating }\end{array}$ & $\begin{array}{c}\text { Infection } \\
(\%)\end{array}$ & $\begin{array}{c}\text { Canker } \\
\text { length } \\
(\mathrm{cm})\end{array}$ & $\begin{array}{c}\text { Canker } \\
\text { margin } \\
\text { rating }\end{array}$ \\
\hline 19 May & 25.0 & 16.2 & $1.1 \mathrm{a}^{\mathrm{x}}$ & 68.8 & 60.5 & $1.0 \mathrm{c}$ & 93.8 & 100.7 & $1.3 \mathrm{c}$ \\
\hline 2 June & 0.0 & --- & -.. & 6.2 & 17.0 & -..w & 6.2 & 110.0 & -.. \\
\hline 17 June & 18.8 & 40.8 & $1.0 \mathrm{a}$ & 87.5 & 52.6 & $2.0 \mathrm{~b}$ & 43.8 & 54.2 & $2.6 \mathrm{~b}$ \\
\hline 30 June & 12.5 & 49.0 & $1.3 \mathrm{a}$ & 37.5 & 27.9 & $1.0 \mathrm{c}$ & 62.5 & 51.5 & $3.0 \mathrm{ab}$ \\
\hline 14 July & 12.5 & 6.5 & $1.0 \mathrm{a}$ & 6.2 & 12.6 & $1.0 \mathrm{c}$ & 6.2 & 10.8 & $4.0 \mathrm{a}$ \\
\hline 28 July & 0.0 & -.- & ... & 31.2 & 8.6 & $3.4 \mathrm{a}$ & 6.2 & 8.7 & $4.0 \mathrm{a}$ \\
\hline 13 Aug. & 0.0 & --- & --- & 0.0 & -- & --- & 0.0 & --- & --- \\
\hline
\end{tabular}

${ }^{2}$ Cankers rated on the basis of canker margin appearance in Apr. 1993, on a scale of 1 to 4: $1=$ severe cracking with well-defined margins, 2 = moderate cracking with moderately defined margins, $3=$ little visible cracking with poorly defined margins, and $4=$ no visible cracking and margins not defined.

${ }^{y}$ Percent infection calculated from the proportion of 16 inoculations per cultivar on each of the seven dates. 'Mean separation in columns by Duncan's multiple range test $(P \leq 0.05)$.

"Where percent infection is greater than 0 , cankers were lost during the season due to breakage or accidental removal-during routine orchard operations.

The trend to form increasingly indeterminate cankers was linear for 'Cortland' and 'Jonathan', based on regression of the mean canker ratings against inoculation date (regression parameters significant at $P \leq 0.05$ ) (Table 2). For 'Delicious', the slope of the linear regression was not significantly different from $0(P \leq 0.05)$ (Table 2$)$. When squared and cubic terms for inoculation date were included in the regression analyses, coefficients of determination were reduced, and parameters often were not significant, indicating that the effect of inoculation date was linear and that no distinct switch-over occurs in canker margin quality. Across all cultivars, $50 \%$ of type 1 cankers (completely determinate) formed from inoculations on 19 May; $65 \%$ of type 2 cankers (mostly determinate) formed from inoculations made on 17 June; $87 \%$ of type 3 cankers (mostly indeterminate) formed from inoculations made on 17 June; and $83 \%$ of type 4 cankers (completely indeterminate) formed from inoculations made on 30 June and 14 and 28 July. For 'Jonathan' (but not for 'Cortland' and 'Delicious'), the number of leaves at inoculation time (and the number of leaves per terminal shoot calculated as percent of the final number of leaves on 30 Aug.) was negatively correlated with canker length $(r=-0.94, P \leq 0.01)$ and positively correlated with canker margin rating $(r=0.95$, $P \leq 0.01)$.

Our results confirm and expand upon those of Beer and Norelli (1977), who found that inoculation of young, nursery-grown trees in midseason (July) produced cankers with determinate margins, whereas those inoculated later in the season (September) produced cankers with indeterminate margins. They recovered E. amylovora from intact canker margin surfaces in $15 \%$ of the 130 cankers examined. The bacterium was recovered more frequently from cankers with indeterminate margins than from those with determinate margins.

The ability of the host to form periderm as a natural defense mechanism maybe the reason why most cankers become determinate and the pathogen inactive. However, there are reports of pathogen isolation from determinate cankers (Beer and Norelli, 1977). Envi- ronmental conditions, such as high humidity and warm weather, and the ability of the plant to absorb soil moisture seem to enhance periderm formation by speeding the rate at which the barrier is produced and ultimately completed (Biggs, 1992). In addition, some workers have suggested that the degree of cultivar resistance may play art important role in wound boundary formation, which affects biochemical qualities of periderms (Biggs, 1992). More research is necessary to determine if apple, like peach [Prunus persica (L.) Batsch], shows variation in the rate of this healing process by cultivar and if there is a correlation between periderm formation and field resistance, or between periderm quality and cultural practices known to affect resistance (i.e., fertilization, irrigation). If such correlations exist, it may be helpful in evaluating cultivar resistance inbreeding programs. Furthermore, such information may be useful to more fully understand canker-forming diseases, such as fire blight, by providing greater insight as to why some pathogens are not fully sequestered and are, therefore, capable of overwintering in cankers.

Table 2. Parameter estimates, coefficient of determination $\left(r^{2}\right)$, and standard error (SE) for the relationship between inoculation date and type of canker formed following artificial inoculation of three apple cultivars with the fire blight bacterium, Erwinia amylovora.

\begin{tabular}{|c|c|c|c|c|}
\hline Cultivar & $\mathrm{b}_{0}$ & $\mathrm{~b}_{1}$ & $\mathrm{r} 2$ & SE \\
\hline Cortland & $\begin{array}{l}-2.76 \\
(1.19)\end{array}$ & $\begin{array}{c}0.0072 \\
(0.0019)\end{array}$ & 0.27 & 0.88 \\
\hline Jonathan & $\begin{array}{l}-5.79 \\
(0.92)\end{array}$ & $\begin{array}{c}0.014 \\
(0.0015)\end{array}$ & 0.71 & 0.61 \\
\hline Delicious & $\begin{array}{l}1.30 \\
(0.67)\end{array}$ & $\begin{array}{r}-0.00036 \\
\left(\begin{array}{ll}0.0001 & 1\end{array}\right)\end{array}$ & 0.0046 & 0.29 \\
\hline
\end{tabular}

Parameter estimates $b_{0}$ and $b_{1}$ are for the regression equation $Y=b_{0}+b_{1} X$, where $Y=$ mean canker rating (based on a scale of 1 to 4 , where $1=$ severe cracking with well-defined margins, $2=$ moderate cracking with moderately defined margins, $3=$ little visible cracking with poorly defined margins, and 4 $=$ no visible cracking and margins not defined), and $\mathrm{X}=$ Julian date. Numbers in parentheses are SES for the parameter estimates. 


\section{Literature Cited}

Beer, S.V. 1979. Fire blight inoculum: Sources and dissemination. EPPO Bul, 9(1):13-25.

Beer, S.V. and J.L. Norelli. 1977. Fire blight epidemiology: Factors affecting release of Erwinia amylovora by cankers, Phytopathology 67:11191125.

Biggs, A.R. 1992. Anatomical and physiological responses of bark tissues to mechanical injury, p. 13-40. In: R.A. Blanchette and A.R. Biggs (eds.). Defense mechanisms of woody plants against fungi. Springer-Verlag, Berlin.

Hockenhull, J. 1974. Some anatomical and pathological features of healthy and diseased haw- thorn (Crataegus monogyna) naturally infected by the fire blight pathogen Erwinia amylovora. Royal Veterinary and Agriculture Univ. Yearbook, Copenhagen, Denmark. p. 125-136.

Miller, P.W. 1929. Studies of fire blight of apple in Wisconsin. J. Agr. Res. 39:579-621.

Sackett, W.G. 1911. Hold-over blight in the pear. Colorado Agr. Expt. Sta. Bul. 177.

SAS Institute. 1987. SAW/STAT guide for personal computers. Version 6 ed. SAS Inst., Cary, N.C.

Schouten, H.J. 1992. Pathological anatomy of fire blight caused by Erwinia amylovora, p. 157 168. In: A.R. Biggs (cd.). Cytology, histology and histochemistry of fruit tree diseases. CRC Press, Boca Raton, Fla.
Steel, R.G.D. and J.H. Torrie. 1980. Principles and procedures of statistics. McGraw-Hill, New York.

Steiner, P.W. and G.W. Lightner.1991. Maryblyt ${ }^{\text {TM}}$. A predictive program for forecasting fire blight disease in apple and pear. Univ. of Maryland, College Park.

van der Zwet, T. 1969. Study of tire blight cankers and associated bacteria in pear. Phytopathology 59:607-613.

van der Zwet, T. and H.L. Keil. 1979. Fire blight: A bacterial disease of Rosaceous plants. Agr. Hdbk. 510, U.S. Dept. of Agriculture, Science and Education Administration, Washington, D.C 